\title{
Evaluation of chemopreventive activity of curcumine lipoiate as an inhibitor of leukemia using nanotechnology
}

\author{
Ahmed Salem ${ }^{1}$, Eman Noaman $^{1}$, Eman kandil $^{2 *}$, Abdelfattah Badawi ${ }^{3}$, Hend Mohamed ${ }^{1}$ \\ and Sara Ashraf ${ }^{1}$ \\ 1-Department of Biochemistry, Faculty of Science, Ain Shams Univ., Cairo, Egypt \\ 2-National Center for Radiation, Research and Technology, Atomic Energy Authority, \\ Cairo, Egypt \\ 3- Petrochemical Department, Egyptian Petroleum Research Institute, Cairo, Egypt \\ * Correspondence author: (email: Kandil.eman@yahoo.com)
}

\begin{abstract}
One of the most dangerous types of cancer is leukemia which is predominant in children more than adult. The present study aimed to evaluate the chemopreventive activity of curcumine lipoiate on tumor progression and hematopoiesis in the peripheral blood either in free form or conjugated with Zinc Oxide nanoparticles (ZnO-NPs) on the incidence of 7,12- dimethylbenz (a) anthrathene (DMBA) induced leukemiain female wistar rats. The activity of $\beta 2$ microglobulin and $\mathrm{CBC}$ in addition to the activities of the most important free radical scavengers of the antioxidant defense system as well as malondialdehyde content were estimated. Liver function and kidney function markers were also determined for all groups. Cytopathological examination of peripheral blood of each group was also performed. The result of the present study revealed that, curcumine lipoiate conjugated with ZnO-NPs, is more potent antitumor effect than in free form, as it normalizes most of the investigated parameters.

In conclusion,these results proved that, the conjugation form resulted in superadditive inhibitor effects on leukemic cells and this was well appreciated with the cytopathological alteration findings in the treated groups, these findings suggest that curcuminelipoiate with Zinc-Oxide play an important role in prevention of leukemia.
\end{abstract}

Key words: Chemopreventive activity, curcumine lipoiate, inhibitor, leukemia, nanotechnology

\section{INTRODUCTION}

One of the most dangerous types of cancer is leukemia which is predominant in children more than in adults. The behavior of leukemia is different than that of other cancers, which usually begin in major organs and ultimately spread to the bone marrow. Leukemia has two types, chronic and acute leukemia, the latter is rapidly progressing leukemia that starts in the bone marrow and causes large number of white blood cells to be produced and enter the blood stream ${ }^{(1)}$.

There are several types of leukemia (acute lymphoblastic leukemia ALL, acute myeloblastic leukemia AML, chronic lymphoblastic leukemia CLL and chronic myeloginous leukemia $\mathrm{CML})^{(2)}$. Although the risk for cancer is multifactorial and often seems to have confusing causes with no easy cures, a substantial portion of cancer incidence rates is believed to be due to environmental factors, including diet and exposure to certain chemicals $^{(3)}$. The magnitude of the contribution to cancer of the bone marrow from exposure to environmental chemicals remains unclear. Nevertheless, one of the agents which has previously been identified to be responsible for the development of neoplasia is the polycyclic aromatic hydrocarbon (PAH), 7,12-dimethylbenz[a] anthracene (DMBA), which is an immuno-suppressor as well as a potent organ-specific carcinogen ${ }^{(4)}$. The mechanism by 


\section{Ahmed Salem et al.}

which DMBA works relies on its capability of inducing oxidative stress and producing reactive oxygen species, which represent the key role in initiating the cancer process ${ }^{(5)}$.

The high prevalence of leukemia provides a strong rationale for identifying new compounds, both natural and synthetic, for use as cancer chemotherapeutic agents with limited side-effects. There is evidence that a variety of chemicals can inhibit, delay, and/or reverse cancer induced by either environmental insults or life style ${ }^{(6)}$.

Natural products are the best way to prevent or treat tumor progression. Curcumin lipoiate proved that it is one of the best way to prevent cancer. The chemical composition of curcumin lipoiate consists of conjugation of curcumin with lipoic acid which are very strong natural antioxidants. Curcumin lipoiate is relatively non toxic with a no effect level.

Deng et al.(7) indicated that nanotechnology has an advantage in cancer therapy and he found that metallic nanoparticles especially Zinc-Oxide nanoparticles activate neural stem cell apoptosis by activating Fas, caspase- 8 and induce mouse epidermal JB6 cell apoptosis. On the other hand, some investigations showed that nanoparticle supplementation can o prevent cancer occurrence. Metal oxide nanoparticles, including zinc oxide, are versatile platforms for biomedical applications and therapeutic intervention ${ }^{(8)}$. In this regard, studies have been reported that $\mathrm{ZnO}-\mathrm{NPs}$ induce selective cytotoxic action on mammalian cancer cells in a cell-specific and proliferation-dependent manner which suggests an exciting potential for $\mathrm{ZnO}-\mathrm{NPs}$ as novel alternatives to cancer therapy ${ }^{(9)}$. However, there are several issues which need to be resolved before translation of zinc oxide nanoparticles into medical use, including a better understanding of the mechanism of their selective cytotoxic action ${ }^{(9)}$.

This study aimed to examine the effects of chemo-preventive activity of curcumine lipoiate on tumor progression, chemotherapeutic efficacy and hematopoiesis in the peripheral blood either in free form or conjugated with the $\mathrm{ZnO}-\mathrm{NPs}$.

\section{Experimental animals and materials:}

\section{MATERIALS AND METHODS}

Wister female rats weighing $50 \pm 20 \mathrm{~g}$ were obtained from Nile Company at Amiria, Cairo. Rats were housed in plastic cages, five rats in each cage in freely fed of rats diet and excess of drinking water at temperature $22 \pm 3 \mathrm{C}^{0}$ at the National Center for Radiation Research and Technology (NCRRT), Cairo.

\section{Chemicals:}

All chemicals were obtained from Sigma Aldrich Company, Egypt.

Curcumin lipoiate, compound was prepared by professor Abdelfattah Badawi, prof. of applied chemistry in Egyptian Petroleum Research Institute (EPRI).

\section{Biosynthesis of curcumin lipoiate according to Kappe ${ }^{(10)}$ :}

First, approximately $2.4 \mathrm{mmol}$ curcumin was weighed and dissolved in $50 \mathrm{ml}$ dioxane. Following the addition of $0.3: 0.73 \mathrm{~g}$ pyridine, $4.8 \mathrm{mmol}$ Lipoic acid was added to the system dropwise. The system was allowed to react for 2 hours in an ice water bath. The reaction was monitored by TLC, which was developed with 3:1 chloroform/ethyl acetate. Second, the product obtained was poured into $40 \mathrm{ml}$ petroleum ether for filtering. The resultant precipitate was dissolved into $30 \mathrm{ml}$ ethyl acetate. The solution was washed twice with $20 \mathrm{ml}$ of $1 \mathrm{~mol} / \mathrm{L}$ hydrochloric acid solution and once with saturated sodium carbonate solution. The resultant material was dried for $2 \mathrm{~h}$ by adding $3 \mathrm{~g}$ anhydrous sodium sulfate. Subsequently filtration was performed and the filtrate was removed by spinning. Then the crude product curcumin Lipoiate was obtained. Third, the above crude product curcumin Lipoiate was loaded onto a silica gel column and diluted with 7:1 petroleum 


\section{Evaluation of chemopreventive activity of curcumine lipoiate as an inhibitor of leukemia using nanotechnology}

ether/chloroform. The target product was collected and dried in vacuum to obtain approximately $1.67 \mathrm{~g}$ final product, i.e. curcumin Lipoiate. Fourth, curcumin Lipoiate prepared by this example was confirmed to possess an expected structure of curcumin Lipoiate by using the micro elemental analysis method as follow:

\begin{tabular}{|l|l|l|l|l|l|l|}
\hline Compound & \multicolumn{2}{|l|}{ Carbon \% (C\%) } & \multicolumn{2}{l|}{ Hydrogen \% (H\%) } & \multicolumn{2}{l|}{ Sulfer \% (S\%) } \\
\hline \multirow{2}{*}{ Curcumin lipoiate } & Found & Calculated & Found & Calulated & Found & Calculated \\
\cline { 2 - 7 } & $26.4 \%$ & $28.6 \%$ & $5.5 \%$ & $5.6 \%$ & $23.9 \%$ & $23.8 \%$ \\
\hline
\end{tabular}

\section{Biosynthesis of curcumin lipoiate/ ZnOnano-composite:}

Two stock solutions of standard Curcumin Lipoiate and its conjugate $\mathrm{ZnO}-\mathrm{NPs}$ were prepared. Approximately $0.0373 \mathrm{gm} / \mathrm{ml}$ Curcumin Lipoiate was dissolved in dimethyl sulfoxide (DMSO), $0.0373 \mathrm{gm} / \mathrm{ml} \mathrm{ZnO}$ was suspended in (DMSO). The 2 solutions were mixed and kept in dark glass containers and stored at $4^{\circ} \mathrm{C}$. A series of dilutions were carried out to achieve a final concentration of curcumin lipoiate $(10,25,50,75 \text { and } 100 \mu \mathrm{g} / \mathrm{ml})^{(11)}$.

\section{Methods:}

\section{Evaluation of antitumor efficacy of the tested compounds:}

The present study was designed to comprise a series of in vitro and in vivo investigations as following;

\section{In vitro studies:}

\section{Viability test:}

\section{Trypan blue exclusion method (1hour experiment)}

The results of this method easily distinguish between viable and nonviable cells, since the former are unstained, small, and round, while the latter are stained and swollen. The traditional method of performing trypan blue cell viability analysis involves manual staining and use of a hemocytometer for counting ${ }^{(11)}$.Ehrlich Ascites Carcinoma (EAC) (mouse tumor) was used to investigate the antitumor activity of curcumin lipoiate and nano-zinc oxide suspension in curcumin lipoiate. The parent line of EAC was supplied through the National Cancer Institute (NCI), Cairo University. The tumor line was maintained in female Swiss albino mice by intrraperitoneal transplantation of $2.5 \times 10^{6}$ cells $^{(12)}$. The antitumor effect and inhibitory concentration $50\left(\mathrm{IC}_{50}\right)$ of curcumin lipoiateand a combination of (curcumin lipoiate $+\mathrm{ZnO}-\mathrm{NPs}$ ) were investigated on the viability ofEhrlich Ascites Carcinoma (EAC).

\section{In vivo study:}

\section{Determination of LD50:}

Traditionally acute oral toxicity testing has focused on determining the dose that kills half of the animals (i.e., the median lethal dose or LD50), the timing of lethality following acute chemical exposure, as well as observing the onset, nature, severity, and reversibility of toxicity ${ }^{(13)}$.

The optimum selected dose for evaluating the in vivo antitumor activity of the novel synthesized curcumin lipoiate was calculated as (1/12) of it's LD50 value, which was $50 \mathrm{mg} / \mathrm{kg}$ (b.w.). Whereas, curcumin lipioate combined to $\mathrm{ZnO}$ nanoparticles were used in a dose equivalent to approximately $50 \%$ of the dose selected for curcumin lipoiate, this equals $25 \mathrm{mg} / \mathrm{kg}$ (b.w.).The in-vivo study was carried out using these doses for experiment. Fresh solutions of the tested compounds were prepared in sterile saline, according to their chosen doses, just prior their administration. 


\section{Ahmed Salem et al.}

\section{Work-flow design:}

In the present study animals were divided into six groups (each group consisting of 10 rats), which were recognized as follows:

G (1) (Normal control):This group comprised normal rats received oral doses of DMSO. Animals were left for 3 months then they were scarified.

Group (2) (Curcumin lipoiate): Animals were intraprotonially injected with curcumin lipoiate three times a week (day other day) in a dose of $50 \mathrm{mg} / \mathrm{kg} \mathrm{b} . \mathrm{w}$. till the end of the experiment.

Group (3) (Curcumin lipoiate $+\mathrm{ZnO}-\mathrm{NPs}$ ): Animals were intraprotonially injected with curcumin lipoiate $+\mathrm{ZnO}-\mathrm{NPs}$ three times a week in a dose of $25 \mathrm{mg}$ of cur.lip $+\mathrm{ZnO}$ /kgb.w.till the end of the experiment.

G(4) (DMBA): Animals were intravenously injected with 7, 12 dimethyl benz (a) anthracene (DMBA) two times a week in a dose of $35 \mathrm{mg} / \mathrm{kg} \mathrm{b.w.}{ }^{(15)}$ till the end of the experiment.

Group (5) (DMBA + Curcumin lipoiate):Animals were intraprotoneally injected with curcumin lipoiate as mentioned in group (2) as well as the injection of DMBA as described in group (4) until the end of the experiment (three months).

G(6) (DMBA + Curcumin lipoiate + ZnO-NPs):Animals were intraprotonially injected with curcumin lipoiate $+\mathrm{ZnO}-\mathrm{NPs}$ as described in group (3) as well as the injection of DMBA as mentioned in group (4).

\section{Experimental protocol (blood sampling and plasma preparation):}

The animals were sacrificed after 3 months from the beginning of cancer induction with or without different protection. Whole blood was collected from heart by syringes and divided into two portions, the first portion was whole EDTA blood and used for the determination of complete blood picture $(\mathrm{CBC})$ automated ${ }^{(16)}$.Also, whole blood used to measure antioxidants status and lipid peroxidation were determined colorimetrically as reduced glutathione content (GSH) and glutathione peroxidase (GPx) measured ${ }^{(17)}$, superoxide dismutase (SOD) ${ }^{(18)}$ and catalase ${ }^{(19)}$ and determination of lipid peroxide level $\left(\mathrm{LPX}^{(20)}\right.$. Liver function indicators were determined colorimetrically as total protein $(\mathrm{TP})^{(21)}$ and albumin ${ }^{(24)}$. Alanine aminotransferase (ALT) and aspartate aminotransferase (AST) ${ }^{(22)}$, alkaline phosphatase (ALP) ${ }^{(23)}$ and $\gamma$ Glutamyl Transferase (GGT) ${ }^{(15)}$ also werecarried out. Kidney function indicators as Creatinine ${ }^{(25)}$, and blood urea ${ }^{(26)}$ were estimated using a diagnostic kit. The other portion was centrifuged and separated plasma was used for the determination of the following: $\beta 2$ microglobulin using ELISAkit which based on the principle of a solid phase enzyme-linked immune sorbent assay (ELISA) ${ }^{(16) .}$

Cytopathological examination: was carried out from peripheral blood smear by staining it with Giems a stain to be examined under microscope ${ }^{(27)}$.

Statistical analysis: All statistical analyses were performed using computerized software, SPSS program (Statistical Packages for Social Sciences, version 15.0) ${ }^{(28,29)}$. Data were analyzed using a one-way analysis of variance (ANOVA), followed by least significant difference (LSD) multiple comparisons test, when an overall significance was indicated by the P-value. The level of significance was set at $P<0.05$ in all cases. All data are reported as the mean \pm S.D. for six rats per each group. 


\section{RESULTS}

The efficiency of curcumin lipoiate alone or conjugated with ZnO-NPs evaluated by both in vitro and in vivo studies.

\section{In vitro study:}

The results were indicated in Table (1). The 50\% growth inhibitory concentration $\left(\mathrm{IC}_{50}\right)$ values for free curcumin lipoiate and it's combination with ZnO-NPs were estimated from the available cytotoxicity. The novel curcumin lipoiate+ZnO-NPs exhibited the strongest in vitro anticancer activity against Erlich Ascited Carcinoma (EAC), it recorded the lowest IC $_{50}$ value $(20 \mu \mathrm{g} / \mathrm{ml})$ comparable to that of free curcumin lipoiate $(50 \mu \mathrm{g} / \mathrm{ml})$ against (EAC).

\begin{tabular}{|c|c|c|c|c|}
\hline $\begin{array}{c}\text { Parameters } \\
\text { Groups }\end{array}$ & $\begin{array}{c}\text { GSH } \\
(\mathbf{m g} / \mathbf{d l})\end{array}$ & $\begin{array}{c}\text { GPx } \\
(\mathbf{0 x i d i z e d ~ G S H} / \\
\mathbf{m l})\end{array}$ & $\begin{array}{c}\text { SOD } \\
(\mathbf{m g} / \mathbf{m l})\end{array}$ & $\begin{array}{c}\text { CAT } \\
(\mathbf{m m o l} / \mathbf{m l})\end{array}$ \\
\hline Control & $61.8 \pm 3.1^{\mathrm{b}}$ & $0.8 \pm 0.04^{\mathrm{b}}$ & $7.2 \pm 0.3^{\mathrm{b}}$ & $0.2 \pm 0.03^{\mathrm{b}}$ \\
\hline curcumin lipoiate & $51.6 \pm 4.9^{\mathrm{ab}}$ & $0.8 \pm 0.13^{\mathrm{b}}$ & $5.9 \pm 0.8^{\mathrm{ab}}$ & $0.2 \pm 0.02^{\mathrm{b}}$ \\
\hline $\begin{array}{c}\text { curcumin } \\
\text { lipoiate+ZnO }\end{array}$ & $55.9 \pm 4.9^{\mathrm{b}}$ & $0.8 \pm 0.16^{\mathrm{b}}$ & $6.9 \pm 0.3^{\mathrm{b}}$ & $0.3 \pm 0.03^{\mathrm{ab}}$ \\
\hline $\begin{array}{c}\text { DMBA } \\
\text { DMBA+ curcumin } \\
\text { lipoiate }\end{array}$ & $12.1 \pm 6.7^{\mathrm{a}}$ & $0.3 \pm 0.09^{\mathrm{a}}$ & $0.2 \pm 0.1^{\mathrm{a}}$ & $0.08 \pm 0.03^{\mathrm{a}}$ \\
\hline $\begin{array}{c}\text { DMBA+ curcumin } \\
\text { lipoiate+ZnO }\end{array}$ & $55.4 \pm 4.4^{\mathrm{ab}}$ & $0.9 \pm 0.19^{\mathrm{b}}$ & $5.1 \pm 0.18^{\mathrm{b}}$ & $0.16 \pm 0.01^{\mathrm{b}}$ \\
\hline
\end{tabular}

Table (1): The $\mathrm{IC}_{50}$ values of Curcumin lipoiate and Curcumin lipoiate combined with ZnO-NPs on Erlich Ascites Carcinoma (EAC).

In vivo study:

Biochemical Analyses:

whole blood Antioxidant defense system:

After three months of treatment, antioxidant activity levels (GSH, GPx, SOD and CAT) were shown to be decreased significantly in the DMBA- induced group (G 4)relative to control group, while there was an improvement in antioxidants levels observed in the treated groups either with urumin lipoiate alone or with its conjugate ZnO NPs compared with the DMBA treated model group. More improvement was observed in group treated with curumin lipoiate $+\mathrm{ZnO}$ NPs comparable with its free form (Table 2). 
Ahmed Salem et al.

\begin{tabular}{|c|c|c|}
\hline Cell line & Curcumin lipoiate & $\begin{array}{l}\text { Curcumin lipoiate combined } \\
\text { with ZnO-NPs (Suspension) }\end{array}$ \\
\hline Erlich cell line & 50 & 20 \\
\hline
\end{tabular}

Table

(2):

Effect of individu al

curcumin lipoiate and its combined form with $\mathrm{ZnO}$-NPs on whole blood antioxidant defense system:

Each value represents the mean of 6 records \pm S.D.

a: significant different vs normal control group.

b: significant different vs DMBA administrated group.

\section{Lipid Peroxidation:}

MDA level was increased significantly in the DMBA treated model relative to control group, but decreased in groups treated with curcumin lipoiate and its conjugated form with ZnO-NPs compared with the DMBA model group (Table 3).

\section{$\beta 2$ microglobulin levels:}

Results in Table (3) showed that, DMBA-treated group displayed a significantly increase in $\beta 2$ microglobulin relative to control group (which would be due to presence of tumors). On the contrary, curcumin lipoiate and curcumin lipoiate/ZnO supplementation significantly decreased the $\beta 2$ microglobulin level. Such that, $\beta 2$ microglobulin was elevated in the DMBA-model compared to both the treated group and the normal control groups.

Table (3): Effect of individual curcumin lipoiate and its combined form with $\mathrm{ZnO}$ nanoparticles on plasma lipid peroxidationand $\beta 2$ microglobulin levels:

\begin{tabular}{|c|c|c|}
\hline Parameters Groups & $\begin{array}{c}\text { MDA } \\
(\mathbf{m m o l} / \mathbf{L})\end{array}$ & $\boldsymbol{\beta 2}$ microglobulin \\
\hline Control & $98.6 \pm 2.1^{\mathrm{b}}$ & $0.7 \pm 0.6^{\mathrm{b}}$ \\
\hline curcumin lipoiate & $108.6 \pm 2.2^{\mathrm{ab}}$ & $0.7 \pm 0.6^{\mathrm{b}}$ \\
\hline curcumin lipoiate+ZnO & $102.6 \pm 1.8^{\mathrm{b}}$ & $0.7 \pm 0.5^{\mathrm{b}}$ \\
\hline DMBA & $310 \pm 25.7^{\mathrm{a}}$ & $112.3 \pm 73.7^{\mathrm{a}}$ \\
\hline DMBA+ curcumin lipoiate & $118.2 \pm 7.1^{\mathrm{ab}}$ & $0.9 \pm 0.5^{\mathrm{b}}$ \\
\hline DMBA+ curcumin lipoiate+ZnO & $94.9 \pm 3.8^{\mathrm{b}}$ & $0.5 \pm 0.4^{\mathrm{b}}$ \\
\hline
\end{tabular}

Each value represents the mean of 6 records \pm S.D.

a: significant different vs normal control group.

b: significant different vs DMBA administrated group.

\section{Complete blood picture (CBC):}




\section{Evaluation of chemopreventive activity of curcumine lipoiate as an inhibitor of} leukemia using nanotechnology

The complete blood picture (CBC) [white blood cells (WBCs) $\left(10^{3} / \mathrm{mm}^{3}\right)$, Red blood cells $(\mathrm{RBCs})\left(10^{6} / \mathrm{mm}^{3}\right)$, hemoglobin $(\mathrm{Hb})(\mathrm{g} / \mathrm{dl})$, Platelets (Plat) $\left(10^{3} / \mathrm{mm}^{3}\right)$, hematocrit

\begin{tabular}{|c|c|c|c|c|c|c|}
\hline $\begin{array}{c}\text { Prameters } \\
\text { Groups }\end{array}$ & MCH(pg) & $\begin{array}{c}\text { MCHC } \\
(\mathrm{g} / \mathrm{dl})\end{array}$ & $\begin{array}{c}\text { Lympho- } \\
(\%)\end{array}$ & $\begin{array}{c}\text { Neutro- } \\
(\%)\end{array}$ & Mono-(\%) & Eosino-(\%) \\
\hline Control & $32.1 \pm 2.3^{\mathrm{b}}$ & $33.1 \pm 0.3^{\mathrm{b}}$ & $28.3 \pm 2.2^{\mathrm{b}}$ & $60.0 \pm 2.6^{\mathrm{b}}$ & $4.9 \pm 0.4^{\mathrm{b}}$ & $6.6 \pm 1.2^{\mathrm{b}}$ \\
\hline $\begin{array}{c}\text { curcumin } \\
\text { lipoiate }\end{array}$ & $32.4 \pm 1.4^{\mathrm{b}}$ & $33.3 \pm 0.0^{\mathrm{b}}$ & $28.4 \pm 4.2^{\mathrm{b}}$ & $60.6 \pm 3.8^{\mathrm{b}}$ & $7.0 \pm 3.4^{\mathrm{b}}$ & $4.0 \pm 2.5^{\mathrm{ab}}$ \\
\hline $\begin{array}{c}\text { curcumin } \\
\text { lipoiate+ZnO }\end{array}$ & $32.3 \pm 0.7^{\mathrm{b}}$ & $33.3 \pm 0.02^{\mathrm{b}}$ & $27.6 \pm 7.3$ & $58.5 \pm 6.6^{\mathrm{b}}$ & $8.3 \pm 2.8^{\mathrm{b}}$ & $6.4 \pm 0.9^{\mathrm{b}}$ \\
\hline DMBA & $27.0 \pm 1.7^{\mathrm{a}}$ & $33.6 \pm 0.5^{\mathrm{a}}$ & $20.5 \pm 0.7^{\mathrm{a}}$ & $2.5 \pm 0.7^{\mathrm{a}}$ & $0.4 \pm 0.9^{\mathrm{a}}$ & $0.0 \pm 0.0^{\mathrm{a}}$ \\
\hline $\begin{array}{c}\text { DMBA+ } \\
\text { curcumin } \\
\text { lipoiate }\end{array}$ & $32.1 \pm 1.9^{\mathrm{b}}$ & $33.3 \pm 0.0^{\mathrm{b}}$ & $55.8 \pm 9.1^{\mathrm{ab}}$ & $40.0 \pm 7.2^{\mathrm{ab}}$ & $3.4 \pm 3.4^{\mathrm{b}}$ & $0.8 \pm 0.8^{\mathrm{a}}$ \\
\hline $\begin{array}{c}\text { DMBA+ } \\
\text { curcumin } \\
\text { lipoiate+ZnO }\end{array}$ & $31.9 \pm 3.1^{\mathrm{b}}$ & $33.1 \pm 0.4^{\mathrm{b}}$ & $61.8 \pm 2.9^{\mathrm{ab}}$ & $31.0 \pm 3.1^{\mathrm{ab}}$ & $5.2 \pm 3.3^{\mathrm{b}}$ & $3.0 \pm 2.1^{\mathrm{ab}}$ \\
\hline
\end{tabular}

(HCT) (\%), MCV (fl), MCH (pg) and MCHC (g/dl), lymphocytes (\%), Neutrophiles (\%), Monocytes (\%) \&Eosinophiles (\%)]were determined in female Wister rats. Data presented in Tables $(4,5)$ showed a highly significant decrease in WBCs count $(\%$ of Neutrophiles, $\%$ of Monocytes, \% of Eosinophiles), RBCs count, hemoglobin concentration, Platelets count and indices of RBCs (HCT,MCV, MCH and lymphocytes) in group with leukemia (G4) compared to control group (G1), but MCHC percentage showed a significant change with control. Whereas, a highly significant increase in lymphocytes percentage was observed in DMBA treated groups either with curcumin lipoiate or curcumin lipoiate $+\mathrm{ZnO}(\mathrm{P}<0.001)$ compared to control. Meanwhile, in all studied groups of animals with leukemia showed a significant improvement with treatment either by curcumin lipoiate (G5) or curcumin lipoiate $+\mathrm{ZnO}(6)$ in WBCs count, \% Neutrophiles, \% Monocytes, \% Eosinophiles, RBCs count, hemoglobin concentration, platelets count and indices of RBCs (HCT, MCV, MCH and $\mathrm{MCHC}$ ). As well as for platelets count, there was a non significant change in platelets count $(\mathrm{p}>0.05)$ in group supplemented with curcumin lipoiate $+\mathrm{ZnO}(\mathrm{G} 3)$ when compared to control group.

Table (4): Effect of individual curcumin lipoiate and its combined form with $\mathrm{ZnO}$ nanoparticles on WBCs, RBCs, Hb, platelets, HCT and MCV.

Each value represents the mean of 6 records \pm S.D.

a: significant different vs normal control group.

b: significant different vs DMBA administrated group.

Table (5): Effect of individual curcumin lipoiate and its conjugated form with ZnO-NPs on MCH, MCHC, lymphocytes, neutrophiles, monocytes and eosinophiles: 
Each value represents the mean of 6 records \pm S.D.

a: significant different vs normal control group.

b: significant different vs DMBA administrated group.

\section{Contents of Plasma Creatinine and Urea:}

According to kidney function indicators, there was a significant increase in the levels of creatinine and urea, in the DMBA received groups. However treatment with curcumin lipoiateandits combined form withZnO-NPs has a significantly improvement in the levels of the kidney function indicators compared with that in the DMBA-model group (Table 6).

Table (6): Effect of individual curcumin lipoiate and its combined form with $\mathrm{ZnO}$ nanoparticles on plasma levels of renal function indicators.

\begin{tabular}{|c|c|c|c|c|c|c|}
\hline \multicolumn{3}{|l|}{ Parameters } & \multicolumn{2}{|c|}{$\begin{array}{c}\text { Creatinine } \\
\text { (mg/dl) }\end{array}$} & \multicolumn{2}{|c|}{$\begin{array}{c}\text { Urea } \\
(\mathrm{mg} / \mathrm{dl})\end{array}$} \\
\hline \multicolumn{3}{|c|}{ Control } & \multicolumn{2}{|c|}{$0.4 \pm 0.1^{b}$} & \multicolumn{2}{|c|}{$41.0 \pm 2.0^{b}$} \\
\hline \multicolumn{3}{|c|}{ curcumin lipoiate } & \multicolumn{2}{|c|}{$0.6 \pm 0.07$} & \multicolumn{2}{|c|}{$41.6 \pm 3.6^{b}$} \\
\hline \multicolumn{3}{|c|}{ curcumin lipoiate+ $\mathrm{ZnO}$} & \multicolumn{2}{|c|}{$0.4 \pm 0.1^{b}$} & \multicolumn{2}{|c|}{$40.6 \pm 2.7^{b}$} \\
\hline \multicolumn{3}{|c|}{ DMBA } & \multicolumn{2}{|c|}{$0.9 \pm 0.09^{\mathrm{a}}$} & \multicolumn{2}{|c|}{$59.8 \pm 3.9^{\mathrm{a}}$} \\
\hline \multicolumn{3}{|c|}{ DMBA+ curcumin lipoiate } & \multicolumn{2}{|c|}{$0.6 \pm 0.15$} & \multicolumn{2}{|c|}{$48.2 \pm 2.1^{b}$} \\
\hline $\begin{array}{l}\text { Paramgtefis } \\
\text { Groups }\end{array}$ & 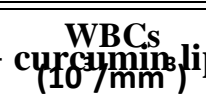 & $\begin{array}{c}\operatorname{RBCs} \\
\text { iattet } \\
\left(0^{t} / \mathrm{mm}^{2}\right)\end{array}$ & $\mathbf{~ H o ( g / d l )} 0$. & $\begin{array}{l} \pm 0 \text { PORelets } \\
\left(10^{3} / \mathrm{cmm}^{3}\right)\end{array}$ & $\operatorname{MCV}^{461)}{ }^{2}=$ & $1.6^{\mathrm{b}}$ \\
\hline Control & $5.1 \pm 0.55^{\mathrm{b}}$ & $4.1 \pm 0.39^{b}$ & $13.2 \pm 0.3^{\mathrm{b}}$ & $220.2 \pm 22.9^{5}$ & $92.6 \pm 11.5^{b}$ & $39.6 \pm 1.1^{\mathrm{b}}$ \\
\hline $\begin{array}{l}\text { curcumin } \\
\text { lipoiate }\end{array}$ & $4.1 \pm 0.24^{\mathrm{ab}}$ & $4.1 \pm 0.1^{\mathrm{b}}$ & $13.1 \pm 0.7^{\mathrm{b}}$ & $181.0 \pm 15.9^{\mathrm{ab}}$ & $97.3 \pm 4.2^{\mathrm{b}}$ & $39.4 \pm 2.2^{b}$ \\
\hline $\begin{array}{c}\text { curcumin } \\
\text { lipoiate }+\mathrm{ZnO}\end{array}$ & $4.0 \pm 0.11^{\mathrm{ab}}$ & $4.1 \pm 0.1^{\mathrm{b}}$ & $13.1 \pm 0.2^{\mathrm{b}}$ & $235.2 \pm 24.2^{\mathrm{b}}$ & $97.0 \pm 2.1^{b}$ & $39.3 \pm 0.7^{b}$ \\
\hline ParBhaleds & $\begin{array}{l}1.2+10 \mathrm{~T} / 5^{\mathrm{a}} \\
\end{array}$ & $3.045105^{\mathrm{a}}$ & $\begin{array}{c}8.1+\mathbf{A}\left(\mathbf{P}^{\mathrm{a}}\right. \\
\mathbf{( H / H )}\end{array}$ & 27.CH.T.9 & $\begin{array}{l}\text { Albumin } \\
\text { 8lbuta } \\
(\mathbf{g} / \mathbf{d} 1)\end{array}$ & $\begin{array}{l}2 \text { Total } 5^{\text {a }} \\
\text { protein }\end{array}$ \\
\hline DMBA+ & & $(\uplus \uplus \mathrm{E})$ & $(\mathrm{U} / \mathrm{t})$ & $(\mathrm{U} / \mathbf{t})$ & & $(\mathrm{g} / \mathrm{dl})$ \\
\hline cuc6umil & $3.9 .6(4) .8^{\text {th }}$ & $8790+0808^{b}$ & $18.8 . \oplus \Theta .6 .2^{b}$ & $1726.849 .6^{9}$ & $96.2 \pm 56^{b}$ & $6832+1.17^{b}$ \\
\hline curसPAate & $28.0 \pm 2.1^{b}$ & $49.2 \pm 1.3^{b}$ & $82.8 \pm 8.0^{b}$ & $28.8 \pm 2.2^{b}$ & $4.1 \pm 0.4^{b}$ & $6.8 \pm 0.5^{b}$ \\
\hline $\begin{array}{c}\text { curfumih } \\
\text { lipgiatedzanes } \\
\end{array}$ & $\begin{array}{l}4.9 \pm 0.63^{b} \\
21.6 \pm 4.8^{b}\end{array}$ & $\begin{array}{l}4.9 \pm 0.63^{b} \\
44.8 \pm 3.8^{b}\end{array}$ & $\begin{array}{r}13.6 \pm 0.8^{b} \\
67.6 \pm 6.7^{b}\end{array}$ & $\begin{array}{l}195.0 \pm 25.0^{b} \\
23.4 \pm 5.7^{b}\end{array}$ & $\begin{array}{l}96.4 \pm 9.1^{b} \\
3.9 \pm 0.8^{6}\end{array}$ & $\begin{array}{l}41.0 \pm 2.4^{b} \\
7.0 \pm 0.5\end{array}$ \\
\hline DMBA & $60.0 \pm 15.0^{\mathrm{a}}$ & $141.4 \pm 32.9^{\mathrm{a}}$ & $323.6 \pm 55.2^{\mathrm{a}}$ & $65.6 \pm 8.8^{\mathrm{a}}$ & $5.0 \pm 0.1^{\mathrm{a}}$ & $7.9 \pm 0.1^{\mathrm{a}}$ \\
\hline $\begin{array}{c}\text { DMBA+ } \\
\text { curcumin } \\
\text { lipoiate }\end{array}$ & $29.2 \pm 3.7^{\mathrm{b}}$ & $68.0 \pm 10.3^{b}$ & $70.8 \pm 5.5^{b}$ & $29.6 \pm 1.1^{\mathrm{b}}$ & $3.9 \pm 0.3^{\mathrm{b}}$ & $6.6 \pm 0.3^{b}$ \\
\hline $\begin{array}{c}\text { DMBA+ } \\
\text { curcumin } \\
\text { lipoiate+ZnO }\end{array}$ & $24.8 \pm 4.7^{b}$ & $57.0 \pm 6.7^{b}$ & $62.8 \pm 9.7^{b}$ & $24.4 \pm 4.5^{b}$ & $4.0 \pm 0.5^{b}$ & $6.7 \pm 0.4^{b}$ \\
\hline
\end{tabular}

Each value represents the mean of 6 records \pm S.D.

a: significant different vs normal control group.

b: significant different vs DMBA administrated group. 


\section{Evaluation of chemopreventive activity of curcumine lipoiate as an inhibitor of leukemia using nanotechnology}

\section{Detrmination of liver functions:}

Liver function tests [aspartate aminotransferase (AST), alanine aminotransferase (ALT), alkaline phosphatase (ALP), $\gamma$ Glutamyltransferase (GGT), total protein (TP), and Alb) were determined in plasma. The results in table (7)showed that, a significant increase in the activity of ALT, AST , ALP, GGT, albumin and Tp of leukemic group without treatment compared to control. There was an improvement in liver enzymes activities in leukemic animals treated with Cur.lipoiate and Cur.lipoiate- $\mathrm{ZnO}$ when compared with leukemic group.

Table (7): Effect of individual curcumin lipoiate and its combined form with ZnO-NPs nanoparticles on plasma levels of liver function indicators.

Each value represents the mean of 6 records \pm S.D.

a: significant different vs normal control group.

b: significant different vs DMBA administrated group.

\section{Cytopathological examination:}

Examination of peripheral blood smears stained with Giemsa stain indicated :.

A: normal blood smear (control) with normal blood cells (c),

B: blood smear of leukemic group, with blast cells (b) that represent an average $74 \%$ of the total WBCs count.

\section{Legends of Figure}

Figures (A, B, C, D, E, F): Photographs of peripheral blood smear of different groups, stained with Giemsa stain, Magnified X 100 .

A: Control group with normal blood cells (c) .

B: Leukemic group, with blast cells (b).

C: Leukemic group supplemented with curcumin lipoiate, showing improved blood film , without blast cells.

D: Leukemic group supplemented with curcumin lipoiate+ ZnO-NPs, showing improved blood film, without blast cells.

E: Group supplemented with curcumin lipoiate NPs , showing normal blood cells.

F: Group supplemented with curcumin lipoiate $+\mathrm{ZnO}-\mathrm{NPs}$, showing normal blood cells. 


\section{Ahmed Salem et al.}

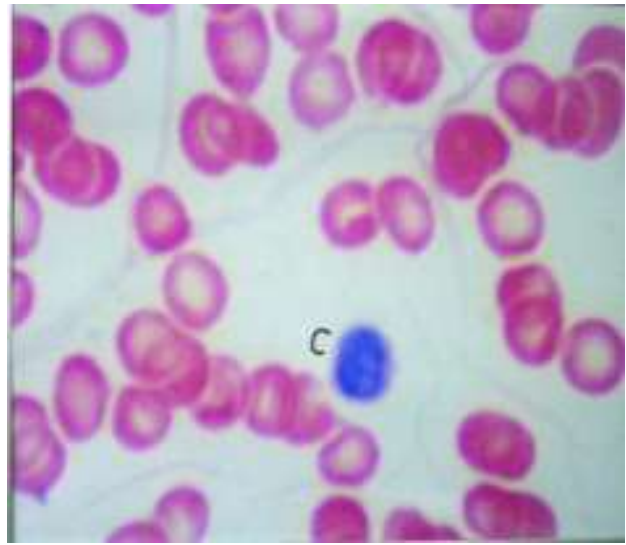

A: Blood smear concerning normal control.

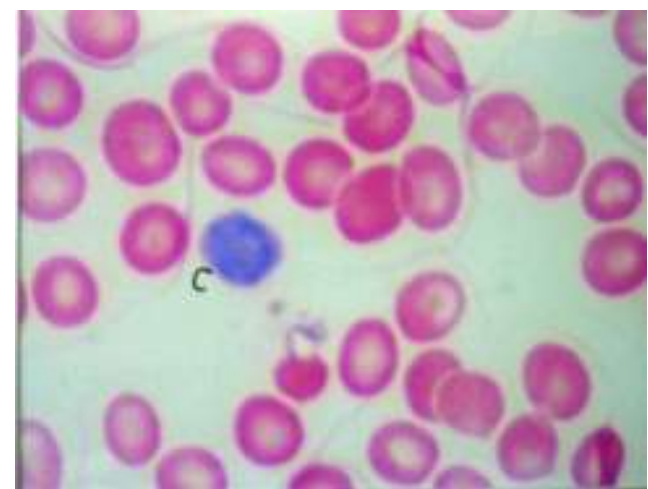

C: Blood smear concerning leukemic group supplemented with curcumin lipoiate alone.

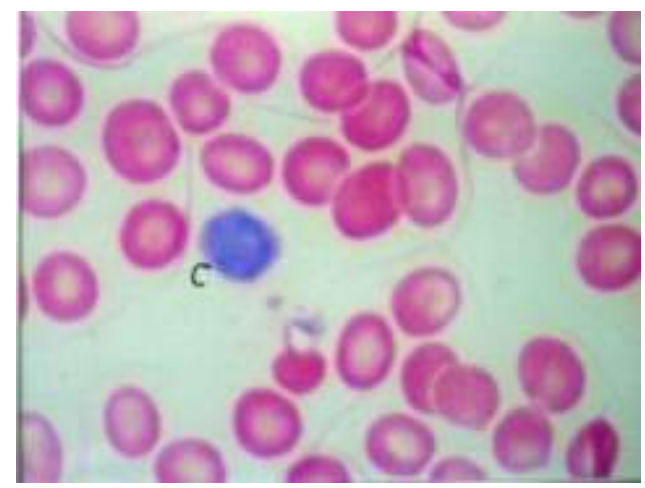

$\mathbf{E}:$ Blood smear concerning group with Curcumin lipoiate only.

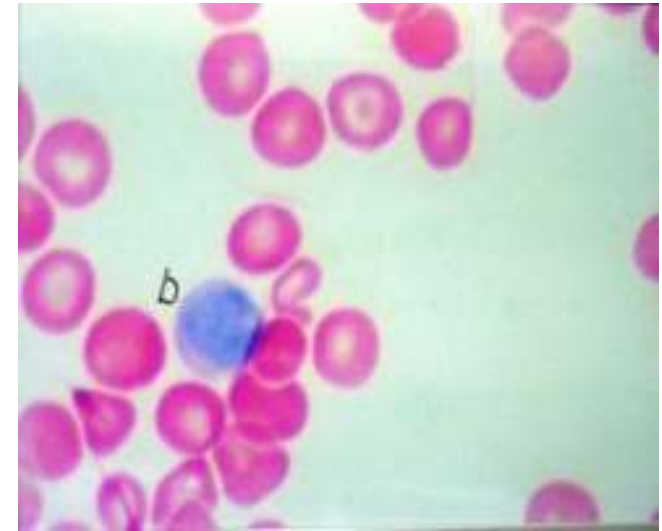

B: Blood smear concerning leukemic group.

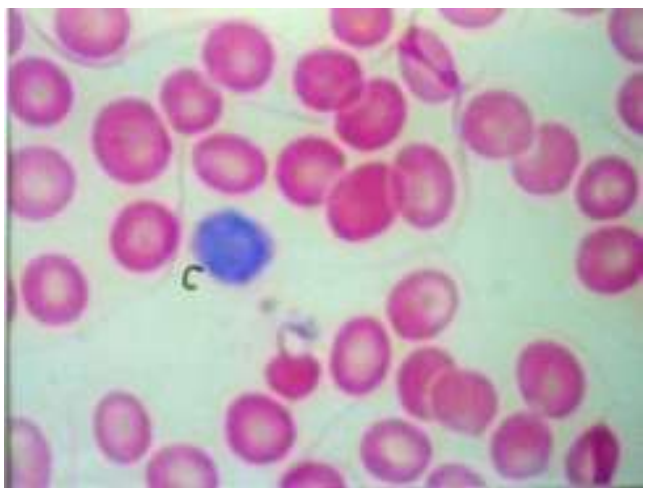

D: Blood smear concerning leukemic group

Supplemented with curcumin lipoiate $+\mathrm{ZnO}$.

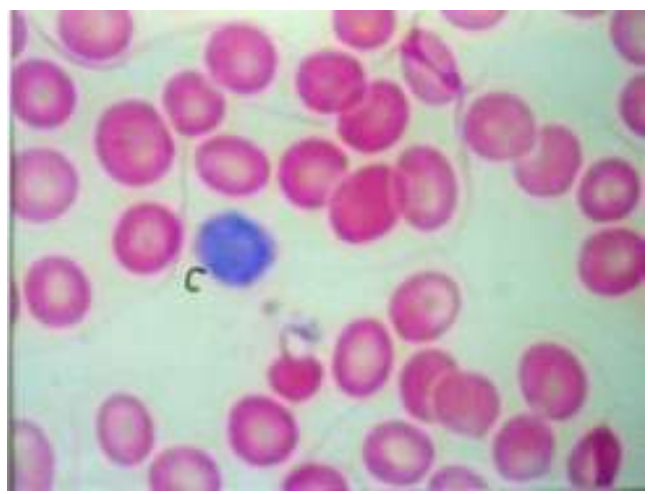

F: Blood smear concerning group with curcumin lipoiate $+\mathrm{ZnO}$. 


\section{Evaluation of chemopreventive activity of curcumine lipoiate as an inhibitor of leukemia using nanotechnology}

\section{DISCUSSION}

There is an increasing evidence that cancer and other mutation related diseases can be prevented not only by avoiding exposure to recognized risk factors but also by favoring the intake of protective factors and by modification of defense and DNA repair mechanisms of the host organism. This strategy referred to as chemoprevention and it is realized by means of suitable pharmacological agents and/or by dietary factors ${ }^{(30)}$. In the present study, the cytotoxiceffects and the biological activities of curcumin lipoiate and curcumin lipoiate combined with $\mathrm{ZnO}-\mathrm{NPs}$ as antitumor agents were evaluated both in vitro and in vivostudies. The in vitro study was conducted to evaluate the cytotoxic effects of the tested compounds on the ErlichAscite Carinoma (EAC) using Trypan blue assay. The results revealed that both curcumin lipoiate and curcumin lipoiate+ZnO-NPs affect cell viability of (EAC). These results are in harmony with early studies which observed in vitro anticancer activity of curcumin compounds against many cancer cell lines(31). Referring to the 50\% growth inhibitory concentration $\left(\mathrm{IC}_{50}\right)$ values, the novel curcumin lipoiate conjugated with $\mathrm{ZnO}$-NPs exhibited the highest in vitro tumoricidal effect against (EAC) which is dose-dependent. Where, it recorded the lowest $\left(\mathrm{IC}_{50}\right)$ comparable to that of curcumin lipoiate alone. These results may suggest that, the action of curcumin lipoiate+ZnO-NPs resulted in super-additive cytotoxic effects on leukemic cancer cells.

The current in vivo study aims to investigate an antitumor activity of curcumin lipoiate which of natural origin either in free form or conjugated with ZnO-NPs. Breast tissue and bone marrow may be a major target for the toxicological effects of a variety of lipophilic carcinogens such as polycyclic aromatic hydrocarbon $(\mathrm{PAH})(32-33)$ respectively. Metabolic activation of DMBA, a member of the PAH family, by cytochrome P450 (CYP) enzymes produces radical cations, free radicals and oxygenated metabolites (epoxides) that bind directly to DNA, presumably leading to genetic mistakes that result in cancers(34). Numerous studies have shown that 7,12-dimethylbenz(a)anthracene (DMBA) can be used to induce experimental leukemia in rats and that this process involves disruption of tissue redox balance; in turn, this suggests that biochemical and pathophysiological disturbances may result from oxidative damage(35).The extent of oxidative stress was evaluated on the basis of its foremost biomarkers such as; activities of some antioxidant defense enzymes and lipid peroxidation end products (MDA, a byproduct of lipid peroxidation).Oxidative stress, resulting from ROS generation, is one out of several etiological and pathophysiological factors implicated in carcinogenesis (36). Kaur et al . (37) reported that, it is considered to be implicated in the path of physiology of breast cancer. Under normal circumstances, ROS are efficiently kept in check by body's elaborate antioxidant defense system which keeps equilibrium between ROS formation and dissipation (36). However, such protective mechanisms can be broken easily by environmental exposure to chemicals, such as DMBA, which disrupt the pro-oxidant-antioxidant balance, leading to cellular anomalies (38). Antioxidant enzymes act as the primary line of defense against ROS which suggest their usefulness in estimating the risk of oxidative damage induced during carcinogenesis(39). Moreover, the study of Arulkumaran et al.(39) inferred that, the biochemical alterations observed in cancer bearing animals may be due to the reduction of antioxidants levels (GSH, GPx, SOD and CAT) following carcinogen (DMBA) administration; which may be due to the utilization of antioxidants to scavenge the free radicals. The decreased level of CAT observed in cancer-bearing animals may be due to the utilization of antioxidant enzymes in the removal of $\mathrm{H}_{2} \mathrm{O}_{2}$ by DMBA. Moreover, decreased level of CAT activity was measured in patients of leukemia and breast cancer diseases (42). Results of the present work revealed a significant 


\section{Ahmed Salem et al.}

increase in the GSH content in both tumor-free and tumor-induced rat groups treated with either our novel curcumin lipoiate alone or combined with ZnO-NPs compared to DMBA group. Similarly, GPx activity also significantly increasedin tumor-induced rat groups treated with curcumin lipoiate alone and curcumin lipoiate+ZnO-NPs compared to DMBA group. Our results revealed that, a significant increase of SOD activity in rat groups treated with either curcumin lipoiate and curcumin lipoiate+ZnO-NPs compared to DMBA group. Furthermore, CAT activity was significantly increased in both rat groups treated with DMBA+curcuminlipoiate and DMBA+curcumin lipoiate+ZnO-NPs with respect to DMBAtreated rat group and these results agreed with previous reports(43).Oxidative stress, especially lipid peroxidation is known to be involved in carcinogenesis (45). Increased levels of lipid peroxidation products play a role in the early phases of tumor growth. So that, in the present study, injection of DMBA intravenously to female Wister rats has been proved to induce significant deleterious changes in antioxidant status. As the results revealed a significant increase in MDA level compared to normal control, these findings were in agreement with previous studies which reported that tumor incidence could cause antioxidant disturbances, acceleration in lipid peroxide, and decrease in GSH content and increase in $\gamma$ glutamyl transpeptidase activity (46). The biochemical findings of DMBA injected group showed noticed elevation in the beta-2 microglobulin, compared to the control group indicating that there is a cancer in the DMBA injected group due to carcinogenicity of DMBA. Our results revealed that, DMBA group pretreated with curcumin lipoiate showed a marked depletion in MDA level as well as $\beta 2$ microglobulin level compared to the DMBA group.Complete blood picture parameters especially platelets, hemoglobin, WBCs,, RBCs and RBCs indices were depleted in DMBA group as agreed with previous study(46). While, there was an improvement in these parameters upon its treatment with curcumin lipoiate and its conjugate $\mathrm{ZnO}$-NPs.Also, differential counting improved in case of pre-treated groups with curcumin lipoiate and its conjugate ZnO-NPs in contrast with DMBA group.Also, liver and kidney functions like (ALT, AST, ALP, TP, GGT, Albumin, Urea and Creatinine) were improved in treated groups with our novel compound more than non treated groups. The results of our study revealed that, curcumin lipoiate and its conjugate $\mathrm{ZnO}$-NPs showed antitumor and hematopoietic effect through it can inhibits over cell proliferation hence, it can prevents formation of blast cell.

In the present study cytopathological findings revealed that pretreatment with curcumin lipoiate and its conjugate $\mathrm{ZnO}$ prevented tumor induction in blood as it prevents leukemia but the results of curcumin lipoiate $+\mathrm{ZnO}$ is more better than of curcumin lipoiate only. There were noticeable normal blood cells in the peripheral blood smears, with normal cell counts, no presence of a typical cells and no evidence for blast cells, as curcumin is potent antiangiogenic agent. In the present study, the results indicated that the antitumor activity of the curcumin lipoiate was significantly enhanced by its conjugate $\mathrm{ZnO}$ nanocomposite.

Hence, Combination of different sized $\mathrm{ZnO}$ nanoparticles curcumin lipoiate could have synergistic cytotoxic effect on leukemic cancer cells, indicating the great potential of $\mathrm{ZnO}-\mathrm{NPs}$ in relevant clinical and biomedical application.From the above mentioned results it can be concluded that, pretreatment of DMBA group with ccurcumin lipoiate $+\mathrm{ZnO}$ NPsShowed more improvement in antioxidant state than that of curcumin lipoiate alone.

\section{REFERENCES}

(1) Turgay S, Sar D, Türkistan E (2005) Knowledge, attitudes, risk factors, and early detection of cancer relevant to the schoolteachers in \% . Zmir. Prev. Med., 40: 636641. 


\section{Evaluation of chemopreventive activity of curcumine lipoiate as an inhibitor of leukemia using nanotechnology}

(2) Hudson, M. M.; Mertens, A. C.; Yasui, Y., et al. (2003). Health status of adult long-term survivors of childhood cancer: A report from the childhood cancer survivor study. JAMA, 290(12): 1583-1592.

(3)Chow, L.W.; Cheung, M.N.; Loo, W.T. and Guan, X.Y. (2003). A rat cell line derived from DMBA-induced mammary carcinoma. Life Sci., 73(1): 27-40.

(4) Miyata, M.; Furukawa, M.; Takahashi, K.; Gonzalez, F.J. and Yamazoe Y. (2001): Mechanism of 7,12-dimethylbenz[a]anthracene-induced immunotoxicity: role of metabolic activation at the target organ. Jpn J Pharmacol., 86(3): 302-309.

(5) Tabaczar, S.; Koceva-Chyla, A.; Czepas, J.; Pieniazek, A.; Piasecka-Zelga J. and Gwozdzinski, K. (2012). Nitroxidepirolin reduces oxidative stress generated by doxorubicin and docetaxel in blood plasma of rats bearing mammary tumor. J. Physiol. Pharmacol., 63(2): 153-163.

(6) Abbadessa, G.; Spaccamiglio, A.; Sartori, M.L.; Nebbia, C.; Dacasto, M.; Di Carlo, F. and Racca, S. (2006). The aspirin metabolite, salicylate, inhibits 7,12dimethylbenz[a]anthracene-DNA adduct formation in breast cancer cells. Int. J. Oncol., 28(5): 1131-1140.

(7) Deng, X.; Luan, Q.; Chen, W.; Wang, Y.; Wu, M.; Zhang, H. and Jiao, Z. (2009). Nanosized zinc oxide particles induce neural stem cell apoptosis. Nanotechnol., 20:115101.

(8) Rasmussen, J.W.; Martinez, E.; Louka, P. and Wingett, D.G. (2010). Zinc oxide nanoparticles for selective destruction of tumor cells and potential for drug delivery applications. Expert Opin Drug Deliv., 7:1063-1077.

(9) Taccola, L.; Raffa, V.; Riggio, C.; Vittorio, O.; Carla Iorio, M.; Vanacore, R.; Pietrabissa, A. and Cuschieri A. (2011). Zinc Oxide nanoparticles as selective killers of proliferating cells. Int. J. Nanomedicine, 6: 1129-1140.

(10) Kappe, C.O. (2004). Controlled microwave heating in modern organic synthesis. Angew. Chem. Int. Ed. Engl., 43:6250,-6284.

(11) Xiong, L. and Zhu, J.K. (2002). Molecular and genetic aspects of plant responses to osmotic stress. Plant Cell Environ., 25 131-139.

(12) Kristine, S. Louis and Andre C Siegel. (2011).Methods Mol. Biol., 740:7-12.

(13) Gupta, M.; Mazumder, V.K.; Vamsi, M.L.M.; Sivakumar, T. and Kandar C.C. (2004). Antisteroidogenic activity of two Indian medicinal plants in mice. J. Ethnopharmacol., 21:2590.

(14) Hodgson, E. (2010). A textbook of modern toxicology, 4th edition. John Wiley \& Sons, Inc.; Hoboken, New Jersy. pp. 672.

(15) Prigozhina, E. L. (1962). Induction of Leukosis in Rats with DMBA and its transplantation. Vopr. Onkol., 8: 64-70.

(16) American Association for Cinical Chemistry (2013). effect of disease on clinical laboratory tests. AACC, press. Washington. D.C.

(17) Clinical Guide to Laboratory Tests (1995). $3^{\text {rd }}$ Edition WB Saunders Company, Philadelphia, PAp.374. National committee for clinical laboratory.

(18) Beutler E.; Duron, O. and Kelly, B.M. (1963). Improved method for the determination of blood glutathione. J. Lab. Clin. Med., 61: 882-888.

(19) Minami, M. and Yoshikawa, H. (1979). A simplified assay method of superoxide dismutase activity for clinical use. Clin. Chim.Acta, 92(3): 337-342.

(20) Johansson, L. H. and Borg, L.A. (1988). A spectrophotometric method for determination of catalase activity in small tissue samples. Anal. Biochem., 174: 331-336.

(21) Yoshioka, T.; Kawada, K.; Shimada, T. and Mori, M. (1979). Lipid peroxidation in maternal and cord blood and protective mechanism against activated-oxygen toxicity in the blood. Am. J. Obstet. Gnecol., 135(3): 372-376. 


\section{Ahmed Salem et al.}

(22)Chromy, V. and Fischer J. (1977). Photometric determination of total protein in lipemic sera. Clin. Chem., 23(4):754-6.

(23) Reitman, S. and Frankel, S. (1957). A method of assaying liver enzymes in human serum. Am. J. Clin. Pathol., 28: 56-58.

(24) German Society for Clinical Chemistry (1972).

(25) Webster, D.; Bignell, A.H.C. and Attwood, E.C. (1974). Clin. Chim. Acta, 53: 101.

(26) Henary, R.J.; D.C. Cannon and W. Winkelman (1974). Clinical chemistry principles and techniques $11^{\text {th }}$ Ed.happer and row public shers, pp: 1629.

(27) Batton, C.J. and Crouch, S.R. (1977). determination of serum urea. Anal.Chem., 49:46446.

(28) Damsgaard, T.E.; Olesen, A.B.; Sorensen, F.B. et al. (1997). Mast cells and atopic dermatitis. Stereological quantification of mast cells in atopic dermatitis and normal human skin. Arch. Dermatol. Res., 289:256-260.

(29) Daniel W.W. (1991). Biostatistics : A foundation for analysis in the health sciences, 5th edition. John Wiley Publishers; New York.

(30) Bailey, T.C. (1994). A review of statistical spatial analysis in geographical information systems. In: Spatial analysis and GIS. Edited by Fotheringham S. and Rogerson P., Eds.; CRC Press, 2013, Ltd.; Taylor and Francis, London. pp. 13- 44.

(31) Aggarwal, S.; Takada, Y.; Singh, S.; Myers, J.N. and Aggarwal, B.B. (2004). Inhibition of growth and survival of human head and neck squamous cell carcinoma cells by curcumin via modulation of nuclear factor-kB signaling. Int. J. Cancer, 111:679-692.

(32) Ohashi, Y.; Tsuchiya, Y.; Koizumi, K.; Sakurai, H. and Saiki, Y. (2003). Prevention of intrahepatic metastasis by curcumin in an orthotopic implantation model. Oncology, 65: 250-258.

(33) Rieder, C.R.M.; Parsons, R.B.; Fitch N.J.S. and Williams, A.C. (2000). Human brain cytochrome P4501B1: immunohistochemical localization in human temporal lobe and induction by dimethylbenz(a)anthracene in astrocytoma cell line (MOG-G-CCM). Neurosci Lett., 278: 177-180.

(34) Batcioglu, K.; Uyumlu, A.B.; Satilmis, B.; Yildirim, B.; Yucel, N.; Demirtas, H.; Onkal, R.; Guzel, R.M. and Djamgoz, M.B. (2012). Oxidative stress in the in vivo DMBA rat model of breast cancer: suppression by a voltage-gated sodium channel inhibitor (RS100642). Basic Clin. Pharmacol. Toxicol., 111(2): 137-141.

(35) Cavalieri, E.; Roth, R. and Rogan, E. (1978). Mechanisms of tumor initiation by polycyclic aromatic hydrocarbons. Carcinogenesis, 3: 273-287.

(36) Dowling, A. P. (2004). Development of nano technologies. Nano-today, 12: 30-35.

(37) Kaur, G.; Lone, I.A.; Athar, M. and Alam, M.S. (2007). Protective effect of Didymocarpuspedicellata on ferric nitrilotriacetate (Fe-NTA) induced renal oxidative stress and hyperproliferative response. Chem. Biol. Interact., 165(1): 33-44.

(38) Kasapovic, J.; Pejic, S.; Todorovic, A.; Stojiljkovic, V. and Pajovic, S.B. (2008). Antioxidant status and lipid peroxidation in the blood of breast cancer patients of different ages. Cell Biochem. Funct., 26(6): 723-730.

(39) Arulkumaran, S.; Ramprasath, V.R.; Shanthi, P. and Sachdanandam, P. (2006). Restorative effect of Kalpa amruthaa, an indigenous preparation, on oxidative damage in breast gland mitochondrial fraction in experimental mammary carcinoma. Mol. Cell Biochem., 291: 77-82.

(40) Cao, Y.; Wang, J.; Henry-Tillman, R. and Klimberg, V.S. (2001). Effect of 7,12dimethylbenz[a]anthracene (DMBA) on gut glutathione metabolism. J. Surg. Res., 100(1): 135-140. 


\section{Evaluation of chemopreventive activity of curcumine lipoiate as an inhibitor of leukemia using nanotechnology}

(41) Gönenç, A.; Erten, D.; Aslan, S.; et al (2006). Lipid peroxidation and antioxidant status in blood and tissue of malignant breast tumor and benign breast disease. Cell Biol. Int., 30: 376-80.

(42) Aggarwal, B.B.; Kunnumakkara, A.B.; Harikumar, K.B.; Tharakan, S.T.; Sung, B.; Anand, P. (2008). Potential of spice derived phytochemicals for cancer prevention. Planta Med.,74: 1560-1569.

(43) Trush, M.A. and T.W. Kensler (1991). An overview of the relationship between oxidative stress and chemical carcinogenesis. Free Radical BioMed., 10: 201-209.

(44) Rice-Evans, C. and Burdon. R. 1993). Free radical-lipid interaction and their pathological consequences. Prog. Lipid. Res., 32: 71- 110.

(45) Khan, N. and Sultana, S. (2004). inhibition of two stages renal carcinogenesis, oxidative damage and hyper proliferative response by Nigelle sativa. Eur. J. cancer prev., 14(2): $159-168$.

(46) John, V.D.; KUttan, G. and Krishnankutty (2002). K. Anti-tumour studies of metal chelates of synthetic curcuminoids. J.Exp. Clin. Cancer Res., 21: 219-224.

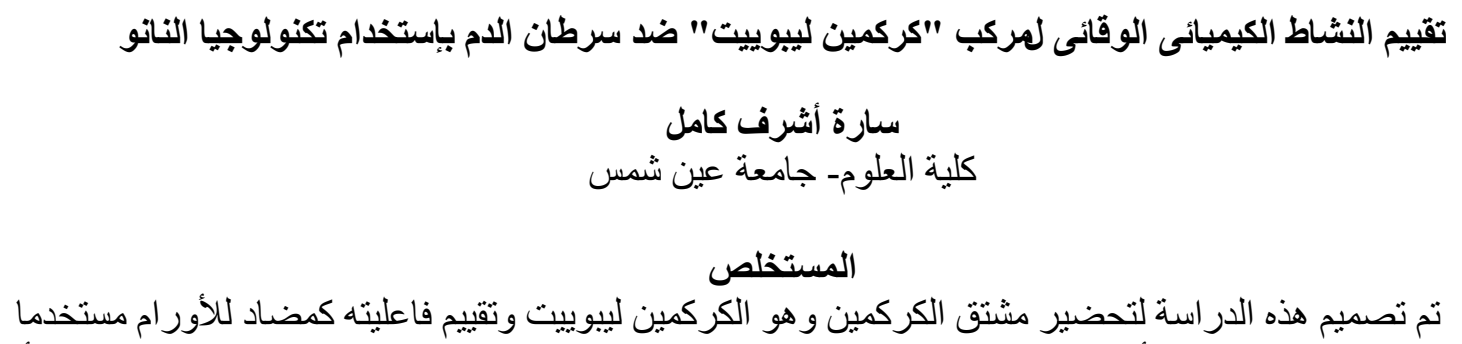

تم تصميم هذه الدراسة لتحضير مشتق الكركمين وهو الكركمين ليبوييت وتقييم فاعليته كمضاد للأور ام مستخدما

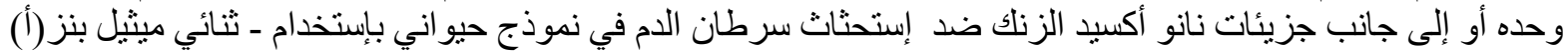

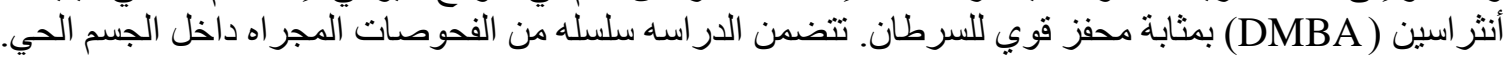

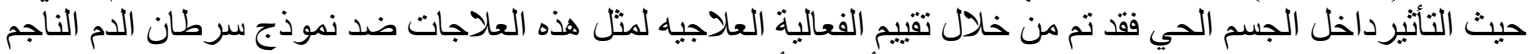

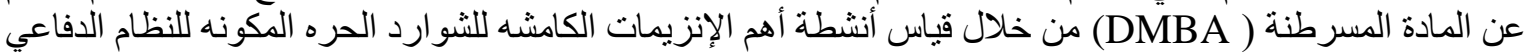

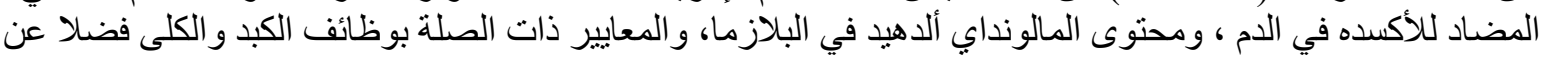

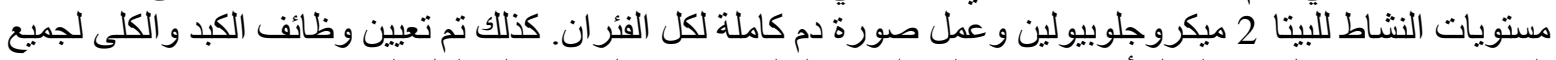

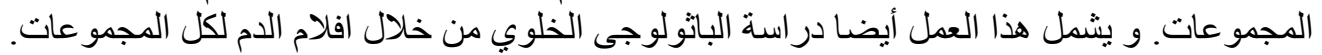

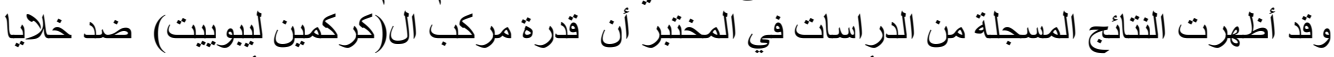

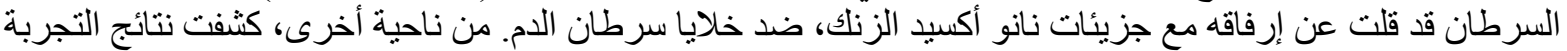

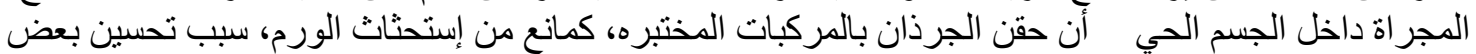

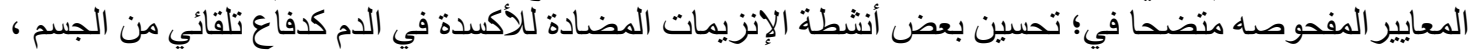

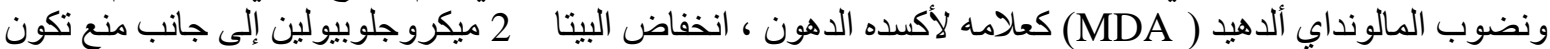

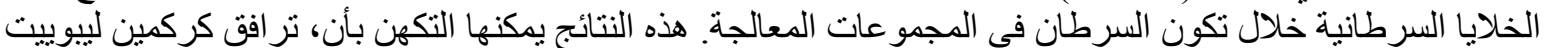

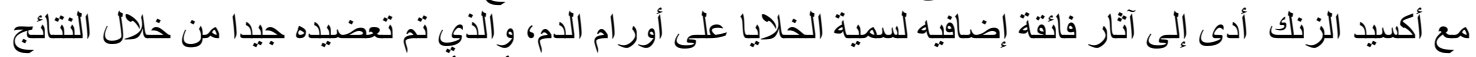

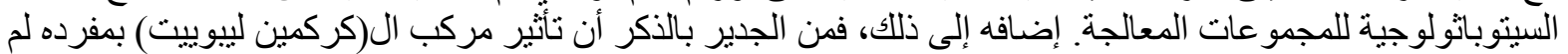

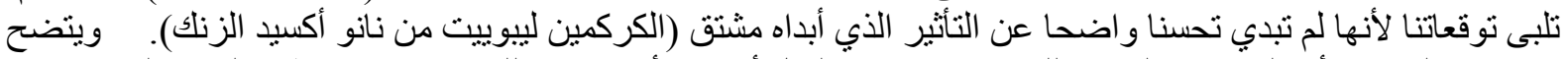

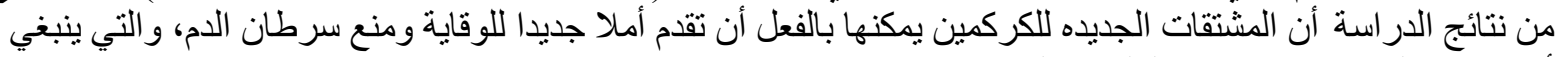
أن تجنذب المزيد من الاهتمام العلمي و الصيدلاني. 